\title{
To Examine the Influence of Emotional Intelligence on Team Outcomes via the Mediating Mechanism of Transformational Leadership
}

\author{
Cheok San Lam ${ }^{1, *} \&$ Eleanor O’Higgins ${ }^{2}$ \\ ${ }^{1}$ International Graduate School of Business, University of South Australia, G.P.O. Box 2471, Adelaide SA 5001, \\ Australia \\ ${ }^{2}$ Graduate Business School, University College Dublin, Carysfort Avenue, Blackrock, Co Dublin, Ireland \\ *Corresponding author: International Graduate School of Business, University of South Australia, G.P.O. Box 2471, \\ Adelaide SA 5001, Australia. Tel: 853-6208-7146. E-mail: san.lamcs@gmail.com
}

Received: July 31, $2014 \quad$ Accepted: January 2, $2015 \quad$ Online Published: January 9, 2015

doi:10.5430/mos.v2n1p120 URL: http://dx.doi.org/10.5430/mos.v2n1p120

\begin{abstract}
The purpose of this paper is to examine the interrelated influences of managers' emotional intelligence, leadership styles and team outcomes of: team performance, team communication, team cohesion and conflict management. In particular, this study explored the potential mediating effects of managers' transformational leadership style on the relationships between managers' emotional intelligence and those team outcomes. The results showed that managers' transformational leadership style fully mediates the relationship between managers' emotional intelligence and team performance, team communication and conflict management. However, no mediating effect of managers' transformational leadership style is found on the relationship between managers' emotional intelligence and team cohesion.
\end{abstract}

Keywords: emotional intelligence; transformational leadership; team outcomes

Emotional intelligence (EI), a powerful competence, is associated with leadership (Wong, 2002) and particularly with transformational leadership style (Barling, Slater, \& Kelloway, 2000; Clarke, 2010; Lindebaum \& Cartwright, 2010; Palmer, Walls, Burgess, \& Stough, 2001). Transformational leaders transform the needs, values, preferences and aspirations of followers from self-interests to collective interests, so followers become highly committed to the leader's mission (Shamir, House, \& Arthur, 1993). Transformational leadership style comprises four dimensions: idealized influence (charisma), inspirational motivation, individual consideration and intellectual stimulation (Bass, 1997).

\section{Purpose of Study and Significance}

Research has been carried out on EI, transformational leadership style and effects on team outcomes. However, limited research has linked all these three concepts together. Both managers' EI (George, 1995; Goleman, 1996; Langhorn, 2004; Prati, Douglas, Ferris, Ammeter, \& Buckley, 2003; Wong \& Law, 2002) and transformational leadership (Bass, 1995; Ozaralli, 2003; Yammarino \& Bass, 1990) are associated with similar positive effects on team outcomes. Therefore, a major objective of our study is to explore the dynamic interplay among the three concepts of EI, transformational leadership and team performance, in particular, the potential mediating role of transformational leadership style on the relationship between managers' EI and team outcomes. Thus, our perspective differs from that of previous studies that focus only on the direct relationship between the causal influences of managers' EI on subordinates' team outcomes.

Most of the EI measures developed in Western countries are elusive because those scales load heavily on the Big-Five personality dimensions (Davies, Stankov, \& Roberts, 1998). The original proponents of EI (Mayer, Salovey, \& Caruso, 2000) argued that EI should be defined as a set of abilities related to emotions. In support of EI as a set of mental abilities, Wong and Law (2002) developed a self-report EI measure (WEIS) which distinguishes the EI construct from Big-Five personality (Law, Wong, \& Song, 2004) by demonstrating EI has predictive power. An 
objective of this study is to add to what is known about the Chinese work context with respect to EI by utilizing a measure of EI that better captures the dynamics of the EI concept within the field of study.

Practically, this study offers directions for management within the burgeoning Chinese economy. China is the largest Foreign Direct Investment (FDI) recipient in the world with foreign enterprises actively pursuing business there. Thus, the results of this study provide valuable information for foreign investors to better deal with Chinese corporations and to function more efficiently in this attractive market on a practical level.

\section{Theoretical Framework and Hypotheses}

\subsection{Literature Review}

\subsubsection{Emotional Intelligence}

Goleman (1998a, p. 317) defined EI as "the capacity for recognizing our own feelings and those of others, for motivating ourselves and for managing emotions well in ourselves and in our relationships". His EI model comprises four dimensions: self-awareness, self-management, social awareness and relationship management. Among the four EI dimensions, Goleman (1996) and Bar-On (1997) identified self-awareness as the most important dimension of EI. Self-awareness is knowing one's emotions, recognizing a feeling as it happens which is the keystone of EI. If someone knows their internal states of emotion, it allows self-control and leads to empathy in others, keeping the individual away from anger, anxiety and gloom and, allow the person to become active in work and life (Goleman, 1996).

Social awareness is recognizing emotions in others. Empathy, another ability that builds on emotional self-awareness, is a fundamental people skill. Empathy is the important component in relationship management, the skill of managing emotions in others (Goleman, 1996).

IQ and technical skills do matter, but mainly as threshold capabilities ... recent research clearly showed that EI is the sine qua non of leadership. Without it, a person can have the best training in the world, an incisive, analytical mind, and an endless supply of smart ideas, but still will not make a good leader (Goleman, 1998a, p. 92).

Indeed, studies have shown that EI exerts a positive influence on employees' work attitudes, behaviors and performance and relates to various job-related outcomes, including job performance (Bachman, Stein, Campbell, \& Sitarenios, 2000; Goleman, 1996; Tischler, Biberman, \& Mckeage, 2002), leadership success (Cooper \& Sawaf, 1997; Higgs, 2003; Sivanathan \& Fekken, 2002), citizenship behaviors (Day \& Carroll, 2004), quality problem solving (Rahim \& Minors, 2003) and conflict management (Rahim et al., 2003).

Rosete and Ciarroch (2005) investigated why intelligent and experienced leaders are not always successful in dealing with environmental demands and life in general by examining the relationship between EI, personality, cognitive intelligence and leadership. Their results revealed that higher EI was associated with leadership effectiveness, and that EI explained the variance not explained by either personality or IQ.

\subsubsection{Leadership Style}

Burns (1978) asserted that a transforming leader "looks for potential motives in followers, seeks to satisfy higher needs, and engages the full person of the follower ... a relationship of mutual stimulation and elevation that converts followers into leaders" (Burns, 1978, p. 4). Bass (1997) established four components of transformational leadership:

1. Idealized influence (charisma) - Leaders are admired as role models generating pride, value, loyalty and confidence. Leaders emphasize trust on difficult issues and the ethical consequences of decisions. 2. Inspirational motivation - Leaders articulate an appealing vision of the future and challenge followers with high standards, providing meaning for what needs to be done. 3. Intellectual stimulation - Leaders question old assumptions and beliefs. Leaders stimulate new perspectives and ways of doing things and encourage the expression of ideas in others. 4. Individualized consideration - Leaders deal with others as individuals, consider subordinates' individual needs and abilities. Leaders also listen attentively and encourage subordinates' development.

Transformational leadership style has been shown to be positively associated with organizational success (Eisenbach, Watson, \& Pillai, 1999), consolidated-business-unit performance (Geyer \& Steyrer, 1998; Howell \& Avolio, 1993), team performance (Bass, 1990), trust in the leader (Podsakoff, Mackenzie, Moorman, \& Fetter, 1990), subordinates' extra effort and satisfaction (Seltzer \& Bass, 1990; Yammarino \& Bass, 1990), and special attention to the needs of subordinates (Barling et al., 2000). Thus, transformational leadership style is considered an important influence on an organization's leaders and subordinates alike, producing a variety of positive outcomes in organizational settings. 


\subsubsection{Team Outcomes/Performance}

Work teams are the focus of this study. Cohen and Bailey (1997) defined work teams as continuing work units responsible for producing goods or services with typically stable, usually full-time, and well-defined membership.

It is a complex task to measure team performance in organizations, since only a few of the group tasks lend themselves to quantifiable measurement (Hackman, 1987). Resources inputs and specific performance indicators might vary from team to team (Dionne, Yammarino, Atwater, \& Spangler, 2004). However, Guzzo and Shea's (1992) and Hackman's (1992) studies indicated that team processes do lend themselves to comparisons across teams. A Dionne et al. (2004) study used only process performance measures to represent team performance, selecting three well-developed, empirically justified teamwork processes, based on previous literature - team cohesion, team communication and conflict management. Thus, in this study, team outcomes, including process-based metrics (team communication, team cohesion and conflict management) and team performance, were used as indicators to measure whether teams can achieve their objectives.

\subsection{Theoretical Framework}

\subsubsection{Managers' Emotional Intelligence and Transformational Leadership}

Studies have found a positive relationship between EI and transformational leadership style (Barbuto \& Burbach, 2006; Barling et al., 2000; Clarke, 2010; Duckett \& Macfarlane, 2003; Harms \& Credé; 2010; Leban \& Zulauf, 2004; Lindebaum \& Cartwright, 2010; Palmer, et al., 2001). The literature has suggested that leaders' ability to understand and manage their own emotions, as well as those of their followers contributes to effective leadership in a variety of positive organizations outcomes (Gardner \& Stough, 2002; George, 2000; Kerr, Garvin, Heaton, \& Boyle, 2006; Rosete \& Ciarrochi, 2005).

Supervisors' emotional intelligence is positively associated with transformational leadership, increasing team effectiveness in subordinates (Polychroniou, 2009). The inspirational motivation and individualized consideration components of transformational leadership are significantly correlated with both the ability of emotional monitoring and management in oneself and others (Palmer et al., 2001). It implies that leaders who motivate and inspire subordinates to work toward common goals (inspirational motivation), and pay special attention to the achievement and developmental needs of subordinates (individualized consideration), monitor and manage emotions both within themselves and others. In a study of 49 managers and 187 subordinates, EI was associated with three aspects of transformational leadership - idealized influence, inspirational motivation, and individual consideration, as emotionally intelligent leaders were inclined to use a transformational style (Barling et al., 2000). Overall EI was correlated with the transformational leader behavior component of inspirational motivation; the individualized consideration components of transformational leadership were significantly correlated with both strategic EI and understanding emotions. Specifically, research shows that emotional intelligence contributes to transformational leadership and subsequent actual project performance (Leban \& Zulauf, 2004).

In investigating whether EI predicted transformational, transactional and laissez-faire leadership styles. Gardner and Stough (2002) showed that EI correlated highly with all dimensions of transformational leadership, and that the components of understanding of emotions and emotional management were the best predictors of transformational leadership style.

\subsubsection{Managers' Emotional Intelligence and Team Outcomes}

Wong and Law (2002) showed that the EI of leaders and followers affects job performance and attitude. An extensive range of studies shows that managers' EI positively accounts for differences in team outcomes (Gardner \& Stough, 2002; George, 2000; Jordan \& Lawrence, 2009; Kerr et al., 2006; Prati, et al, 2003) and team attitudes (group satisfaction, cohesiveness and effectiveness) (Offermann, Bailey, Vasilopoulos, Seal, \& Sass, 2004). Managerial EI is positively related to employee profit performance (Langhorn, 2004), and leader's positive mood was associated with team performance in a service setting (George, 1995). Leaders in positive affective states may energize the people they manage, causing them to approach tasks actively and enthusiastically, as they have high levels of confidence in their ability to succeed. "Recognizing and expressing feelings enables leaders to take advantage of and use their positive emotions and emotional information to facilitate organization performance, including prioritizing demands and solving problems" (Gardner \& Stough, 2002, p. 77). Leaders motivate team members to work together toward team goals, challenging team members to work toward increasing team effectiveness and performance. To benefit the team, leaders must be able to establish strong emotional relationships with team members, based on their EI.

Managers with high EI are able to handle the negative feelings of subordinates. This helps to eliminate 
disagreements and conflict through excellent communication to achieve the highest synergy within a team, enhancing its internal harmony and goal achievement (Goleman, 1996, 1998a). This working environment leads to enhanced team communication, cohesion and conflict management.

\subsubsection{Managers' Transformational Leadership and Team Outcomes}

Assertions have been made regarding the beneficial effect of transformational leadership on subordinates. Studies have found that employees are willing to exert more effort and to increase standards for transformational leaders (Seltzer \& Bass, 1990; Yammarino \& Bass, 1990), and to have higher performing work groups and receive higher ratings of effectiveness and performance (Bass, 1995; Bryman, 1992; Duckett \& Macfarlane, 2003). Bass (1995) claimed that transformational leaders have higher performing work groups because high level transformational leaders can move followers to exceed expectations and to generate extra effort, creativity, and productivity.

Transformational leadership is positively correlated with team performance by arousing affiliation motives among followers, creating cohesion (Keller, 2006; Yammarino \& Bass, 1990). Transformational leaders influence team environment when they change the attitudes of their followers in collective goals and even convince them to attain higher ones. (Bass, Avolio, Jung, \& Berson, 2003; Koene, Vogelaar, \& Soeters, 2002; Rowold \& Heinitz, 2007). In addition, transformational leaders provide alternative solutions to problems, so are able to convert follower negative feelings of frustration to constructive ones, which leads to heightened followers' performance (McColl-Kennedy \& Anderson, 2002). Ozaralli (2003) found that transformational leadership contributed to the prediction of team effectiveness with respect to team innovation, communication and performance. Others also confirmed that transformational leadership is associated with a higher level of team cohesiveness, in contrast to transactional leadership (Stashevsky \& Koslowsky, 2006).

\subsubsection{The Proposed Mediating Role of Managers' Transformational Leadership}

Thus far we have reviewed research on the links between: managers' EI and transformational leadership; managers' EI and team outcomes; as well as managers' transformational leadership style and team outcomes: team performance, team communication, team cohesion and conflict management. The main proposal in this study is that transformational leadership mediates the relationship between emotional intelligence and team outcomes.

In a South Korean public-sector organization analysed at the group level, Hur, Van den and Wilderom (2011) showed that transformational leadership mediates the relationships between emotional intelligence and leader effectiveness, as well as service climate. In a study of 51 department managers and 252 employees in Taiwan, Wang, Huang and Tung-Chun (2009) found that both emotional intelligence and group cohesiveness are positively associated with transformational leadership. In addition, transformational leadership mediates the relationship between leaders' emotional intelligence and group cohesiveness.

A number of authors have theorized that EI is antecedent to transformational leadership (Barling et al., 2000; Brown \& Moshavi, 2005; Cooper \& Sawaf, 1997; Goleman, 1998b). There are three reasons why individuals high in EI would be more likely to use transformational behaviours (Barling et al., 2000). Firstly, they link self-awareness and self-management to idealized influence as "leaders who know and can manage their own emotions, and who display self-control and delay of gratification, could serve as role model for their followers, thereby enhancing followers' trust in and respect for their leaders." (Barling et al., 2000, p. 157). Secondly, they link social awareness to inspirational motivation. Thirdly, they link relationship management to individualized consideration as the ability to understand followers' needs and interact empathetically, thereby managing relationships positively. In reviewing the findings of previous authors, it was seen that EI serves as a building block for emotional competence, which combines or interacts with other factors leading to performance (Brown, Bryant, \& Reilly, 2006). Thus, it can be assumed that EI should occur before transformational leadership.

We propose that the power of managers' EI on those outcomes must go through a third variable - transformational leadership. Managers' EI would therefore have no direct relationship with those outcome variables, and any relationship between the two could only be because of the mediating effect of transformational leadership. Managers' EI on its own will not lead to those outcomes. According to Baron and Kenny (1986), the first condition of a mediator is that variations in levels of the independent variable significantly account for variations in the presumed mediator (i.e., managers' EI can predict transformational leadership style), as the mediator accounts for the dependent variable (team outcomes). This is how a manager's transformational leadership may play a mediator role in the relationship between that manager's EI and team outcomes.

Therefore, we hypothesize:

Hypothesis 1 Managers' transformational leadership style mediates the positive relationship between managers' EI 
and team performance.

We also predict that leadership mediates the relationship between EI and separate team processes:

Hypothesis 2 Managers' transformational leadership style mediates the positive relationship between managers' EI and team communication.

Hypothesis 3 Managers' transformational leadership style mediates the positive relationship between managers' EI and team cohesion.

Hypothesis 4 Managers' transformational leadership style mediates the positive relationship between managers' EI and conflict management.

Figure 1 describes a model encompassing proposed relationships among EI, leadership style, and effects on team various team outcomes. The rationale behind this model follows.

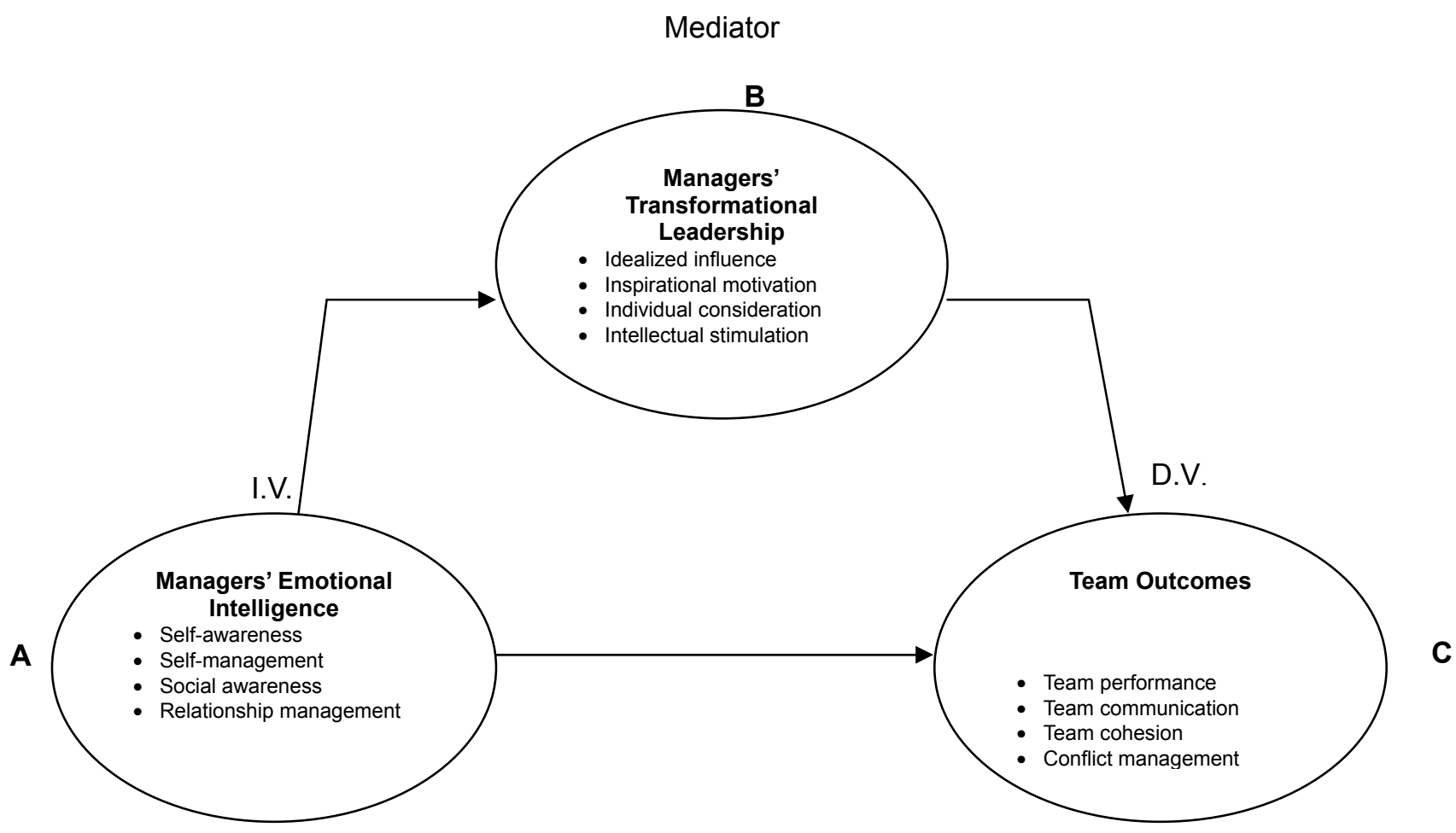

Figure 1. Conceptual Framework

\section{Methods}

\subsection{Sample and Procedure}

The data for this study were obtained from two Chinese privately owned enterprises in Shanghai in the construction industry. Shanghai is in the vanguard of modern Chinese business_since the Chinese government has turned the city into a major international financial centre. Thus, the construction industry is one of the fastest growing business sectors, driven by a soaring real estate market. Companies that supply building materials are also growing synchronously.

The questionnaires were distributed by one of the authors who gave guarantees that all the information provided by respondents would be kept strictly anonymous and confidential.

The sample for this study included all the managerial and non-managerial employees in the two companies. A total of 709 questionnaires were distributed to 94 team managers and 615 subordinates. We received 347 responses, yielding a 48.94 percent response rate. Twenty-four of the returned questionnaires were excluded from the analysis because of missing pages. This left a valid sample of 323. A total of 50 teams were involved in the study. Table 1 describes characteristics of the sample. 
Table 1. Samples, Means and Standard Deviations of Main Variables

\begin{tabular}{llll}
\hline & N & Mean & SD \\
\cline { 2 - 4 } Managers' EI & 50 & 24.28 & 5.33 \\
Transformational leadership & 323 & 2.40 & 0.63 \\
Subordinates' Gender & 273 & 1.27 & .45 \\
Subordinates' Age & 273 & 36.16 & 9.10 \\
Subordinates' Education Level & 273 & 2.57 & .69 \\
Subordinates' Work Experience & 273 & 3.01 & 1.76 \\
Managers' Gender & 50 & 1.3 & .46 \\
Managers' Age & 50 & 44.12 & 10.14 \\
Managers' Education Level & 50 & 2.77 & .69 \\
Managers' Work Experience & 50 & 4.38 & 1.90 \\
\hline
\end{tabular}

Gender $0=$ Female, $1=$ Male

Education Level 1=Primary, 2=Secondary, 3=Diploma, 4=Bachelor, 5=Master or above

Work Experience $1=1-5$ years, $2=6-10$ years, $3=11-15$ years, $4=16-20$ years, $5=21-25$ years,

$6=26-30$ years, $7=31$ years or above

Of the sample, 72.4 percent were male. Within the non-manager group, the age of respondents ranged from 19 to 65 and the mean was 36.16 years, with 22.9 percent in the 28 - to 32 -year-old age group. Within the manager sample, the age of respondents ranged from 23 to 67 and the mean was 44.12 years old with 19.5 percent in the 33 - to 37-year-old age group. Of the non-managers, 47.1 percent had a secondary education. Of the managers, most participants had completed a diploma (54.2 percent). Of the non-managers, the highest percentage of work experience is within the range 6 to 10 years (26.4 percent). Within the managerial group, the highest percentage of work experience is within the range of 31 years or above ( 20.8 percent).

The survey instruments were administered in the target companies during work hours. The data were collected through hard copy questionnaires. Based on the information provided by the top management of the companies, a coding system on the surveys was used to associate employees with their direct manager in pairs. Thus, one manager was identified in each team with their employees. Although the team leaders may have a different position title, such as team coordinator, manager, supervisor or executive, they are all classified as "Manager". The survey instruments were administered in Chinese. The scoring of the questions was completed following the method provided by the initial authors.

\subsection{Measures}

Wong Emotional Intelligence EI Scale (WEIS). The Wong, Law, and Wong (2004) 40-item forced choice EI measure for Chinese respondents was used to assess the level of EI in managers as it was suitable for the Chinese participants. The WEIS comprises forced choice items that avoid the problem of social desirability (WEIS) for Asian, especially for Chinese people (Law et al., 2004). Managers completed this self-report EI measure scale. An example WEIS items is: "When you are very down, you will: A. Try to do something to make yourself feel better. B. Just ignore it because you know your emotion will be back to normal naturally". The Cronbach's $\alpha$ for this scale in this study was 0.66 .

Transformational leadership style. To measure transformational leadership, we adopted 20 items from the Multifactor Leadership Questionnaire (MLQ-5x Short; Bass \& Avolio, 1997), a widely accepted assessment instrument of transformational, transactional and laissez-faire leadership styles. It is a 5-point Likert-type frequency measure that asks the respondents to state the frequency with which a number of statements apply to them, from $0=$ not at all to $4=$ frequently, if not always. This part of the questionnaire included both self and other rater versions. Part A assesses leadership style as measured by managers themselves. Part B assesses the leadership style of managers as judged by immediate subordinates. An example of these items for the self-rated version for managers is: "I consider an individual as having different needs, abilities, and aspirations from others". An example of these items for subordinates rating their immediate managers is: "My immediate supervisor considers me as having different needs, abilities, and aspirations from others". The Cronbach's $\alpha$ for the transformational leadership styles scale was 0.90. Rating managers' leadership through assessments by both the managers views of themselves and their direct subordinates' view of them was consistent with previous studies (Barling, Weber, \& Kelloway, 1996; Brown et al., 2006; Ozaralli, 2003; Rosete \& Ciarroch, 2005).

Team outcomes measures. The employees judged four team outcomes: team performance, team communication, 
team cohesion and conflict management.

Team performance - A 5-item scale by Williams (1988) was used to measure overall team performance. This scale has been used in China (Hui, Law, \& Chen, 1999; Wong \& Law, 2002). Respondents described their agreement with each of five statements concerning their feelings about overall team performance on a 7-point Likert-scale ranging from 1 = strongly disagree to 7 = strongly agree. An example of these items is: "Our team always completes the duties specified in our job description”. The Cronbach's $\alpha$ for this scale in this study was 0.88 .

Team communication - A 3-item questionnaire by Campion, Medsker, and Higgs (1993) was used to measure team communication. This measure has been used in a Chinese sample by Scott, Bishop, and Chen (2003). It is a 7-point Likert-scale ranging from 1 = strongly disagree to $7=$ strongly agree. An example of these items is: "Members of my team are very willing to share information with other team members about our work". The Cronbach's $\alpha$ for this scale in this study was 0.86 .

Team cohesion - We adopted a 3-item questionnaire by Jehn and Mannix (2001) with a Likert-type 7-point scale ranging from $1=$ not at all to $7=a$ lot. An example of these items is: "How much do you feel like your team has group spirit?" The Cronbach's $\alpha$ for this scale in this study was 0.83 .

Conflict management - Conflict management was assessed by a 3-item questionnaire by Green and Taber (1980) with a Likert-type 7-point scale ranging from $1=$ strongly disagree to $7=$ strongly agree. An example of these items is: "This team resolves the differences that exist among team members in a timely fashion". The Cronbach's $\alpha$ for this scale in this study was 0.84 .

Control variables. Past studies showed that demographic variables such as gender, age, education level and work experience may be correlated to EI and transformational leadership style as well as team outcomes. Thus, these variables were employed as control variables.

The Chinese version of the scale of WEIS, Multifactor Leadership Questionnaire was applied. Since there were no available Chinese versions of the scales for team performance, team communication, team cohesion and conflict management, the English versions of these scales were translated into Chinese and then back-translated to ensure the respondents would be clear about the questions, and to ensure equivalency of meaning (Brislin, 1980).

\section{Results}

\subsection{Verification Analysis}

Table 2 presents the correlation between variables in the study. Managers' EI was positively correlated to transformational style $(\mathrm{r}=.23, p<.01)$. In addition, managers' $\mathrm{EI}$ is positively correlated to all of the team outcomes - team performance $(\mathrm{r}=.18, p<.01)$, team communication $(\mathrm{r}=.23, p<.01)$, conflict management $(\mathrm{r}=.17$, $p<.01)$ and team cohesion $(\mathrm{r}=.11, p<.05)$.

Table 2. Inter-Correlations of Main Variables

\begin{tabular}{|c|c|c|c|c|c|c|c|c|c|c|}
\hline Variables & 1 & 2 & 3 & 4 & 5 & 6 & 7 & 8 & 9 & 10 \\
\hline 1. Managers' EI & $(0.66)$ & & & & & & & & & \\
\hline 2. Transformational Leadership & $.23 * *$ & $(.90)$ & & & & & & & & \\
\hline 3. Team Performance & $.18 * *$ & $.38 * *$ & $(.88)$ & & & & & & & \\
\hline 4. Team Communication & $.23 * *$ & $.35^{* *}$ & $.74 * *$ & $(.86)$ & & & & & & \\
\hline 5. Team Cohesion & $.11 *$ & $.37 * *$ & $.65 * *$ & $.54 * *$ & $(.83)$ & & & & & \\
\hline 6. Conflict Management & $.17 * *$ & $.33 * *$ & $.73 * *$ & $.70 * *$ & $.53 * *$ & $(.84)$ & & & & \\
\hline 7. Gender & -.07 & .07 & .05 & -.04 & 0 & -.03 & $(\mathrm{~N} / \mathrm{A})$ & & & \\
\hline 8. Age & $.25 * *$ & -.04 & $.22 * *$ & $.21 * *$ & .10 & .12 & .05 & $(\mathrm{~N} / \mathrm{A})$ & & \\
\hline 9. Education Level & .06 & 0 & $.20 * *$ & $.13 *$ & $.16^{* *}$ & $.14 *$ & $.19 * *$ & -.01 & $(\mathrm{~N} / \mathrm{A})$ & \\
\hline 10. Work Experience & $.16^{* *}$ & .04 & $.20 * *$ & $.21 * *$ & .10 & .06 & .07 & $.85 * *$ & .06 & $(\mathrm{~N} / \mathrm{A})$ \\
\hline
\end{tabular}

Cronbach's alpha values are provided along the diagonal in parentheses; N/A not applicable.

$* *$ correlation is significant at 0.01 level (2-tailed)

* correlation is significant at 0.05 level (2-tailed)

Managers' transformational leadership is positively correlated to all of the team outcomes: team performance $(\mathrm{r}=.38$, $p<.01)$, team communication $(\mathrm{r}=.35, p<.01)$, team cohesion $(\mathrm{r}=.37, p<.01)$ and conflict management $(\mathrm{r}=.33, p$ $<.01)$. 
As shows in Table 2, the correlation between all the independent variables (managers' EI, transformational leadership and four demographic factors) are less than 0.6. Thus, no multicollinearity occurred.

\subsection{Hypothesis Testing}

Mediated regression analysis. Table 3 presents the results of the Mediated Regression Analysis. Following the three-step process described by Baron and Kenny (1986), Model 1 regressed the mediator (managers' transformational leadership style) on the independent variable (managers' EI) and the control variables (gender, age, education level and work experience). In Model 2, the outcomes (team performance, team communication, team cohesion and conflict management) were separately regressed on managers' EI and the control variables. Lastly, in Model 3, the outcomes were separately regressed on managers' EI and transformational leadership style and on the control variables.

Table 3. Mediating Regression Analysis of Transformational Leadership on Team Outcomes

\begin{tabular}{|c|c|c|c|c|c|c|c|c|c|}
\hline \multirow[t]{2}{*}{ Variables } & \multicolumn{2}{|l|}{ Model 1} & \multicolumn{3}{|c|}{ Model 2} & \multicolumn{4}{|c|}{ Model 3} \\
\hline & $\begin{array}{l}\text { Transformational } \\
\text { leadership } \\
\beta\end{array}$ & $\begin{array}{l}\text { Team } \\
\text { performance } \\
\beta\end{array}$ & $\begin{array}{l}\text { Team } \\
\text { communication } \\
\beta\end{array}$ & $\begin{array}{l}\text { Team } \\
\text { cohesion } \\
\beta\end{array}$ & $\begin{array}{l}\text { Conflict } \\
\text { management } \\
\beta\end{array}$ & $\begin{array}{l}\text { Team } \\
\text { performance } \\
\beta\end{array}$ & $\begin{array}{l}\text { Team } \\
\text { communication } \\
\beta\end{array}$ & $\begin{array}{l}\text { Team } \\
\text { cohesion } \\
\beta\end{array}$ & $\begin{array}{l}\text { Conflict } \\
\text { management } \\
\beta\end{array}$ \\
\hline \multicolumn{10}{|l|}{ Controls: } \\
\hline Gender & .15 & .19 & .01 & .04 & -.01 & .11 & -.08 & -.09 & -.09 \\
\hline Age & -.01 & $.04 * *$ & .03 & .03 & $.05 * *$ & $.04 * *$ & $.04 *$ & .03 & $.05 * *$ \\
\hline Education level & -.01 & $.27 *$ & .17 & $.35^{*}$ & .29 & $.28 * *$ & .18 & $.36^{* *}$ & .30 \\
\hline Work experience & -.01 & -.12 & -.08 & -.11 & $-.24 * *$ & -.11 & -.07 & -.10 & $-.23 * *$ \\
\hline \multicolumn{10}{|l|}{ Main effect: } \\
\hline Managers' EI & $.05 * *$ & $.05 * *$ & $.07 * *$ & .04 & $.05 * *$ & .02 & .04 & -.01 & .03 \\
\hline \multicolumn{10}{|l|}{$\begin{array}{l}\text { Mediating } \\
\text { effect: }\end{array}$} \\
\hline $\begin{array}{l}\text { Transformational } \\
\text { leadership }\end{array}$ & & & & & & $.56 * *$ & $.64 * *$ & $.88 * *$ & $.55^{* *}$ \\
\hline Overall $\mathrm{R}^{2}$ & .14 & .16 & .14 & .07 & .11 & .26 & .23 & .24 & .18 \\
\hline $\begin{array}{l}\text { Overall Adjusted } \\
\mathrm{R}^{2}\end{array}$ & .11 & .14 & .11 & .05 & .09 & .24 & .20 & .21 & .16 \\
\hline$\Delta \mathrm{R}^{2}$ & & & & & & .10 & .09 & .17 & .07 \\
\hline $\mathrm{F}$ & $6.66 * *$ & $7.97 * *$ & $6.77 * *$ & $3.13 *$ & $5.51^{* *}$ & $12.59 * *$ & $10.37 * *$ & $10.96 * *$ & $7.95 * *$ \\
\hline $\mathrm{df}$ & 214 & 214 & 214 & 214 & 214 & 213 & 213 & 213 & 213 \\
\hline
\end{tabular}

** correlation is significant at 0.01 level (2-tailed)

*correlation is significant at 0.05 level (2-tailed)

Model 1 showed that managers' EI is significantly related to managers' transformational leadership style ( $\beta=.05, p$ $<.01)$ in a positive way. Model 2 showed that managers' EI is significantly and positively related to team performance $(\beta=.05, p<.01)$, team communication $(\beta=.07, p<.01)$ and conflict management $(\beta=.05, p<.01)$. However, managers' EI is not significantly related to team cohesion. Lastly, Model 3 showed that the relationship between managers' EI and team performance, team communication and conflict management become non-significant when the managers' transformational leadership style (the mediator) is presented. All of the F values for the above models are significant at the 0.01 level. This suggests that managers' transformational leadership style fully mediates the relationship between managers' EI and team performance, team communication and conflict management, and the $\Delta \mathrm{R}^{2}=.10, .09, .07$ respectively. However, no mediating effect of managers' transformational leadership style is found on the relationship between managers' EI and team cohesion since it does not meet the condition that managers' EI should be significantly related to team cohesion at model 2. Thus, hypothesis 1, 2, 4 are confirmed and hypothesis 3 cannot be supported.

We further analyzed team cohesion on a multiple regression independently without combining the managers' EI in Table 3 in model 3. The results (Table 4) show that managers' transformational leadership is directly related to team cohesion. Thus, it can be concluded that team cohesion is caused by managers' transformational leadership. 
Table 4. Result of Multiple Regression Analysis: Managers' Transformational Leadership and Team Cohesion

\begin{tabular}{ll}
\hline Variables & Team cohesion \\
\hline Controls: & $\beta$ \\
Gender & -.08 \\
Age & .03 \\
Education level & $.36^{* *}$ \\
Work experience & -.10 \\
Transformational leadership & $.87^{* *}$ \\
Overall ${ }^{2}$ & .24 \\
Overall Adjusted $\mathrm{R}^{2}$ & .22 \\
$\mathrm{~F}$ & $13.18^{* *}$ \\
\hline
\end{tabular}

** correlation is significant at 0.01 level (2-tailed)

*correlation is significant at 0.05 level (2-tailed)

\section{Discussion}

\subsection{Conceptual Implications}

Previous research focused primarily on how emotional intelligence and transformational leadership achieved higher levels of individual performance (Avolio \& Yammarino, 2002; Bass 1985, 1990). However, there is not much significant literature on achieving higher levels of team performance in relation to EI and leadership styles. Keller (2006, p. 202), calling for more team based studies, observed that "transformational leadership literature has focused too narrowly on dyadic process". Our study focusing on the team level, fills an important gap in the literature. Moreover, our results indicate findings of significance in understanding the dynamic relationships among EI and team outcomes, in particular the mediating role of transformational leadership. Specifically, we explored the dynamic interplay among the concepts studied by evaluating the mediating role of transformational leadership style on the relationship between managers' EI and four important team outcomes (team performance, team communication, team cohesion and conflict management).

The use of the forced choice WEIS in this study is an appropriate instrument to study the phenomenon of EI in a Chinese population. With a valid EI measure, our study was able to ascertain to what extent the relationships found among EI, leadership style and team outcomes in Western contexts, could be understood in the same way in the Chinese context.

By discovering how transformational leadership plays a mediating role between managers' EI and team outcomes, our model is different from previous studies that focus only on the direct relationship between the causal influences of managers' EI on subordinate team outcomes. It provides an in-depth understanding in explaining how the interrelated influences of managers' EI and leadership style enhance team outcomes, which would supplement and emphasize current perspectives, and show that the power of managers' EI on those outcomes must go through a third variable - transformational leadership.

The results show that transformational leadership can explain the dynamics by which managers' EI accounts for team performance, team communication and conflict management. Therefore, managers' EI on its own will not lead to team performance, team communication and conflict management unless it is expressed through transformational leadership.

The changing and complex nature of the Chinese cultural background must be considered in light of the study findings. Tsui, Wang, Xin, Zhang and Fu (2004) claimed that managerial behavior in contemporary China is shaped by multiple influences. The most relevant are: traditional (Confucian) values, Communist ideologies, economic reform, and infiltration of foreign, especially Western, management philosophies and practices.

The role of emotions in Chinese culture is found to be quite different from the one in the US and other Western countries, whereby experienced emotion is irrelevant either to the creation or the perpetuation of social institutions of any kind (Potter, 1988). Asians, especially Chinese, are deemed to accept greater power differences between superior and subordinate roles than their Western counterparts. Also, Asians, are trained to suppress and regulate their emotions, while Westerners are trained to express them. Thus, in Asia, a non-reactive quiet response to a challenging situation may be regarded as a highly emotionally intelligent in Chinese culture. (Wong et al., 2004, p. 538). 
However, since China adopted economic reform and the policy of opening to the outside world in 1978, traditional cultural characteristics have been influenced by Western culture and this has had a significant impact on the leadership style that the Chinese have adopted. The Chinese culture is widely believed to be changing away from typically paternalistic and autocratic structures in both highly bureaucratic state-owned enterprises and private sector enterprises alike. This is particularly so in rapidly growing industries, open to trade with foreign countries. Younger ones who have grown up since China have introduced market reforms in the late 1970s, are more individualistic and less respectful to those in positions of authority (Walumbwa, Lawler, Avolio, Wang, \& Shi, 2005).

At the same time, Chen, Beck and Amos (2005) proposed that "collectivist cultures in Chinese society provide leaders with ready-made opportunities to become transformational leaders". This is based on young, modern managerial cohorts, unaffected by the Cultural Revolution, having received a 'normal' education, and the chance to study abroad. Thus, consistent with the literature, our study finds evidence that Chinese management is more dependent on transformational leadership which emphasizes direct interpersonal relationships. This is one of the reasons that EI needs to be expressed through transformational leadership to produce team performance, team communication and conflict management.

Managers with high EI easily understand and manage the emotions of themselves and others. This competence pushes managers to employ a transformational leadership style that ultimately enhances team outcomes. Although managers with high EI are more sensitive to their own and other's emotions, unless this sensitivity has transferred to some kind of leadership behavior through which employees can feel the manager's concern for them, this positive outcome may not occur.

Although these findings are based on samples drawn from China, certain generalizations appear warranted. Transformational leadership is general, and

The paradigm is sufficiently broad to provide a basis for measurement and understanding that is as universal as the concept of leadership itself. Here, universal does not imply constancy of means, variances, and correlations across all situations, but rather explanatory constructs good for all situations (Bass 1997, p. 130).

Support for the universality of the transformational leadership model comes from Kirkman, Chen, Farh, Chen and Lowe (2009) who conducted cross-cultural research on relationships involving transformational leadership, power distance orientation, procedural justice and organizational citizenship behavior in the US and China. Their study demonstrated that the cross-level impact of transformational leadership on procedural justice and organizational citizenship behavior is similar in both the US and China, as they did not detect country-level differences in transformational leadership effects.

\subsection{Implications for Research}

The study findings point to some future research directions. The Chinese case, with its traditional values and dynamic flux from international influences is particularly revealing about the relationship between environmental effects and personal characteristics, such as emotional intelligence and behavior, such as types of leadership. Moreover, Chinese companies and leaders are changing as fast as the economy is growing China (Tsui et al., 2004). Thus, longitudinal studies on emotional intelligence and leadership style to monitor these changes would be very enlightening.

This study has provided some solid evidence, but studies invoking more variables could be conducted. Types of task such as front line versus back office might have a moderating effect, as employees may require high emotional labor to perform certain front line tasks (Wong \& Law, 2002). Therefore, it is suggested that a model for combining moderation and mediation should be tested. Also, a follow-up to this study could take a finer-grained approach to examine how the individual components of EI (self-awareness, self-management, social awareness and relationship management) and of transformational leadership ( idealized influence, inspirational motivation, intellectual stimulation, individualized consideration) interact to produce employee groups' positive outcomes effects.

There are other factors that may influence relationships among EI, leadership style and team outcomes that can be studied in further research. These include job nature, workloads, working environment, personal high levels of EI or a combination of their managers' EI and their own, instead of being influenced only by their managers' EI. Further studies should explore EI and transformational leadership alongside these and other contextual factors. Thus, the addition of other contextual and personal variables may provide a fuller model of the relationships between EI, transformational leadership and employee outcomes.

The findings are based on samples drawn from one city in mainland China. Future research could replicate the 
current study in different samples and different industries, as well as other national cultures. Further study along the same lines is warranted to fill the gap in this area by using more cross-cultural samples to examine the interrelated effects of emotional intelligence and leadership style.

\subsection{Implications for Practice}

With respect to contributions to management practice, the findings suggest that both EI and transformational leader style enhance organizational welfare. Both these qualities should be considered in management recruitment. Both attributes can also be developed through training. Further, the study suggests that training in EI alone is insufficient to create subordinate team effectiveness if its effects are mediated by transformational leadership. It also suggests that selection for training in transformational leadership should concentrate on individuals with relatively higher EI to be more successful in leading teams.

\subsection{Limitations}

This study had several limitations. The construct and measures of EI have been the subject of some debate. Self-report measures of EI and team outcomes were used to assess a person's self-perception of those variables rather than the actual variables themselves. In some circumstances, such as labor intensive situations, performance-based measures have limitations and self-report is a better way of capturing employees' own sense of team outcomes (Paulhus \& Vazire, 2007; Robins, Norem, \& Cheek, 1999). However, future efforts should be directed in finding ways of assessing performance more objectively instead of self-reporting.

Desirability and common method biases are often a problem in interpreting results in self-report type assessment instruments. In our study these were somewhat mitigated. We reduced social desirability bias by employing a forced choice EI measure geared to Chinese respondents (Wong et al., 2004). In order to eliminate common method bias, for the questionnaire design, some reversed questions were set. In addition, measures of the variables were obtained from different sources, which means that not all the variables used only self-report measures. For instance, managers' leadership style measure was tested using a both self and rater-evaluation method, i.e., leadership style as measure by managers themselves and by subordinates' perception of their immediate managers, that of their subordinates to provide objectivity.

Additionally, a careful choice of assessment instrument and the clarity of items, i.e., the elimination of item ambiguity can help to control common method bias (Podsakoff, Mackenzie, Lee, \& Podsakoff, 2003; Van de Vijver, \& Tanzer, 2004). Thus, applicable and valid instruments with discrete and clear items were chosen carefully in this study. The Cronbach's $\alpha$ (alpha) for the Wong EI scale (WEIS) in this study is 0.66 . DeVellis (1991) suggested that Alpha coefficient between 0.65 and 0.70 implies an acceptable reliability level. This acceptability is upgraded in the framework of the forced choice questions with only two possible reactions, either A or B on the WEIS.

\section{Conclusion}

Notwithstanding these limitations, the main conclusions regarding the mediating role of managers' transformational leadership on the positive relationship between EI and desirable team outcomes can be accepted. These conclusions offer both conceptual and practical implications that are tenable in both Chinese and Western contexts.

\section{References}

Avolio, B. J., \& Bass, B. M. (1990). The full range of leadership development: Basicladvanced manuals. Binghamton, New York: Bass/Avolio and Associates.

Avolio, B. J., \& Yammarino, F. J. (2002). Transformational and Charismatic Leadership: The Road Ahea. Elsevier Science, Oxford.

Bachman, J., Stein, S., Campbell, K., \& Sitarenios, G. (2000). Emotional intelligence in the collection of debt. International Journal of Selection and Assessment, 8(3), 176-182. http://dx.doi.org/10.1111/1468-2389.00145

Barling, J., Slater, F., \& Kelloway, E. K. (2000). Transformational leadership and emotional intelligence: An exploratory study. Leadership and Organization Development Journal, 21(3), 157-161. http://dx.doi.org/10.1108/01437730010325040

Barling, J., Weber, T., \& Kelloway, E. K. (1996). Effects of transformational leadership training and attitudinal and financial outcomes: A field experiment. Journal of Applied Psychology, 81(6), 827-832. http://dx.doi.org/10.1037/0021-9010.81.6.827 
Bar-On, R. (1997). Bar-On emotional quotient inventory: A measure of emotional intelligence: Technical manual. New York: Multi Health Systems.

Baron, R. M., \& Kenny, D. (1986). The moderator-mediator variable distinction in social psychological research: Conceptual, strategic, and statistical considerations. Journal of Personality and Social Psychology, 51(6), 1173-1182. http://dx.doi.org/10.1037/0022-3514.51.6.1173

Bass, B. M. (1985). Leadership and performance beyond expectations. New York: Free Press.

Bass, B. M. (1990). From transactional to transformational leadership: Learning to share the vision. In R. M. Steers, L. W. Porter \& G. A. Bigley (Eds.), Motivation and leadership at work. Boston, MA: McGraw-Hill.

Bass, B. M. (1995). Theory of transformational leadership redux. Leadership Quarterly, 6(4), 463-478. http://dx.doi.org/10.1016/1048-9843(95)90021-7

Bass, B. M. (1997). Does the Transactional-Transformational leadership paradigm transcend organizational and national boundaries? American Psychologist, 52(2), 130-139. http://dx.doi.org/10.1037/0003-066X.52.2.130

Bass, B. M., \& Avolio, B. J. (1997). Full range leadership development: Manual for multifactor leadership questionnaire. CA: Mindgarden.

Bass, B. M., Avolio, B. J., Jung, D. I., \& Berson, J. L. (2002). Leadership effects on organizational climate and fieadersh performance: Local leadership effect in chain organizations. Leadership Quarterly, 13, 193-215. http://dx.doi.org/10.1016/S1048-9843(02)00103-0

Bass, B. M., Avolio, B. J., Jung, D. I., \& Berson, Y. (2003). Predicting unit performance by assessing transformational and transactional leadership. Journal of Applied Psychology, 88(2), 207-218. http://dx.doi.org/10.1037/0021-9010.88.2.207

Brislin, R. W. (1980). Translation and content analysis of oral and written material, In H. C. Triandis \& J. W. Berry (Eds.), Handbook of cross-cultural psychology: Vol. 2. Methodology (pp. 349-444). Boston: Allyn \& Bacon.

Brown, F. W., \& Moshavi, D. (2005). Transformational ledership and emotional intelligence: A potential pathway for an increased understanding of interpersonal influence. Journal of Organizational Behavior, 26(7), 867-871. http://dx.doi.org/10.1002/job.334

Brown, F. W., Bryant, S. E., \& Reilly, M. D. (2006). Does emotional intelligence - as measured by the EQI-influence transformational leadership and/or desirable outcomes? Leadership and Organization Development Journal, 27(5), 330-351. http://dx.doi.org/10.1108/01437730610677954

Bryman, A. (1992). Charisma and Leadership in Organizations. CA, Sage: Newbury Park.

Burns, J. M. (1978). Leadership. New York: Harper and Row Publishers.

Campion, M., Medsker G., \& Higgs, C. (1993). Relationship between work group characteristics and effectiveness: Implications for designing effective work groups. Personnel Psychology, 46(4), 823-850. http://dx.doi.org/10.1111/j.1744-6570.1993.tb01571.x

Chen, H. C, Beck, S. L., \& Amos, L. K. (2005). Leadership styles and nursing faculty job satisfaction in Taiwan. Journal of Nursing Scholarship, 37(4), 374-380. http://dx.doi.org/10.1111/j.1547-5069.2005.00064.x

China Daily. (2008). Per capita GDP predicted to soar by 2030: economist. Retrieved March 26 from http://china.org.cn

Ciarrochi, J., Deane, F. P., \& Anderson, S. (2002). Emotional intelligence moderates the relationship between stress and mental health. Personality and Individual Difference, 32(2), 197-209. http://dx.doi.org/10.1016/S0191-8869(01)00012-5

Clarke, N. (2010). Emotional intelligence and its relationship to transformational leadership and key project manager competences. Project Management Journal, 41(2), 5-20. http://dx.doi.org/10.1002/pmj.20162

Cohen, S. G., \& Bailey, D. E. (1997). What makes teams work: Group effectiveness research from the shop floor to the executive suite. Journal of Management, 23(3), 239-290. http://dx.doi.org/10.1177/014920639702300303

Cooper, R. K., \& Sawaf, A. (1997). Executive EQ: EI in leadership and organizations. Grosset/Putnam, New York.

Davies, M., Stankov, L., \& Roberts, R. D. (1998). Emotional intelligence: In search of an elusive construct. Journal of Personality and Social Psychology, 75(4), 989-1015. http://dx.doi.org/10.1037/0022-3514.75.4.989

Day, A. L., \& Carroll, S. A. (2004). Using an ability-based measure of EI to predict individual performance, group 
performance, and group citizenship behaviors. Personality and Individual Difference, 36(6), 1443-1458. http://dx.doi.org/10.1016/S0191-8869(03)00240-X

DeVellis, R. F. (1991). Scale development. Newbury Park, NJ: Sage Publications.

Dionne, S. D., Yammarino, F. J., Atwater, L. E., \& Spangler, W. D. (2004). Transformational leadership and team performance. Journal of Organizational Change Management, 17(2), 177-193. http://dx.doi.org/10.1108/09534810410530601

Eisenbach, R., Watson, K., \& Pillai, R. (1999). Transformational leadership in the context of organizational change. Journal of Organizational Change Management, 12(2), 80-88. http://dx.doi.org/10.1108/09534819910263631

Gardner, L., \& Stough, C. (2002). Examining the relationship between leadership and emotional intelligence in senior level managers. Leadership and Organization Development Journal, 23(2), 68-78. http://dx.doi.org/10.1108/01437730210419198

Gates, G. (1995). A review of literature on leadership and emotional: Exposing theory, posing questions, and forwarding an agenda. The Journal of Leadership Studies, 2(4), 98-110. http://dx.doi.org/10.1177/107179199500200408

George, J. M. (1995). Leader positive mood and group performance: The case of customer service. Journal of Applied Social Psychology, 25(9), 778-794. http://dx.doi.org/10.1111/j.1559-1816.1995.tb01775.x

George, J. M. (2000). Emotions and leadership: The role of emotional intelligence. Human Relations, 53, 1027-1055. http://dx.doi.org/10.1177/0018726700538001

Geyer, A. L. J., \& Steyrer, J. M. (1998). Transformational leadership and objective performance in banks. Applied Psychology: An International Review, 47(3), 397-420. http://dx.doi.org/10.1080/026999498377917

Goleman, D. (1996). Emotional intelligence: Why it can matter more than IQ. London: Bloomsbury Publishing.

Goleman, D. (1998a). Working with emotional intelligence. New York: Bantam Books.

Goleman, D. (1998b). What makes a leader. Harvard Business Review. (November-December). 93-102.

Green, S., \& Taber, T. (1980). The effects of three social decision schemes in decision group performance. Organizational Behavior and Human Performance, 25(1), 97-106. http://dx.doi.org/10.1016/0030-5073(80)90027-6

Guzzo, R. A., \& Shea, G. P. (1992). Group performance and intergroup relations in organizations. In M. Dunnette \& L. Hough (Eds), Handbook of industrial and organizational psychology (pp. 268-313). Chicago: McNally.

Hackman, J. R. (1987). The design of work teams. In J. Lorsch (Ed.), Handbook of organization behavior. 315-342. Englewood Cliffs, NJ: Prentice Hall.

Hackman, J. R. (1992). Group influences on individuals in organizations. In M, Dunnette \& L. Hough (Eds), Handbook of industrial and organizational psychology (pp. 199-267). Chicago: McNally.

Harms \& Credé, M. (2010). Emotional intelligence and transformational and transactional leadership: A meta-analysis. Journal of Leadership and Organizational Studies, 17(1), 5-17. http://dx.doi.org/10.1177/1548051809350894

Higgs, M. (2003). How can we make sense of leadership in the 21st century? Leadership and Organization Development Journal, 24(5), 273-284. http://dx.doi.org/10.1108/01437730310485798

House, R. J., Hanges, P. J., Ruiz-Quintanilla, S. A., Dorfman, P. W., Javidan, M, Dickson, M., \& Gupta, V. (1999). Cultural influences on leadership and organizations: Project GLOBE. Advances in Global Leadership, 1, 171-233.

Howell, J. M., \& Avolio, B. J. (1993). Transformational leadership, transactional leadership, locus of control, and support for innovation: Key predicators of consolidated-business-unit performance. Journal of Applied Psychology, 78(6), 891-902. http://dx.doi.org/10.1037/0021-9010.78.6.891

Hui, C., Law, K. S., \& Chen, Z. X. (1999). A Structural equation model of the effects of negative affectivity, leader-member exchange and perceived job mobility on in-role and extra-role performance: A Chinese case. Organizational Behavior and Human Decision Processes, 77(1), 3-21. http://dx.doi.org/10.1006/obhd.1998.2812

Hur YoungHee, Van den Berg., \& Wilderom (2011). Transformational leadership as a mediator between emotional 
intelligence and team outcomes. The Leadership Quarterly, 22, 591-603. http://dx.doi.org/10.1016/j.leaqua.2011.05.002

Jehn, K. A., \& Mannix, E. A. (2001). The Dynamic nature of conflict: A Longitudinal study of intragroup conflict and group performance. Academy of Management Journal, 44(2), 238-251. http://dx.doi.org/10.2307/3069453

Jordan, J. J., \& Lawrence, S. A. (2009). Emotional intelligence in teams: Development and initial validation of the short version of the Workgroup Emotional Intelligence Profile (WEIP-S). Journal of Management and Organization, 15, 52-469. http://dx.doi.org/10.5172/jmo.15.4.452

Keller, R. T. (2006). Transformational leadership, initiating structure, and substitutes for leadership: A longitudinal study of research and development project. Journal of Applied Psychology, 91, 202-210. http://dx.doi.org/10.1037/0021-9010.91.1.202

Kelloway, E. K., Barling, J., \& Helleur, J. (2000). Enhancing transformational leadership: The roles of training and feedback. Leadership and Organization Development Journal, 21(3), 145-149. http://dx.doi.org/10.1108/01437730010325022

Kerr, R., Garvin, J., Heaton, N., \& Boyle, E. (2006). Emotional intelligence and leadership effectiveness. Leadership and Organization Development Journal, 27, 265-279. http://dx.doi.org/10.1108/01437730610666028

Kerr, R., Garvin, J., Heaton, N., \& Boyle, Y. (2003). Predicting unit performance by assessing transformational and transactional leadership. Journal of Applied Psychology, 88, 207-218. http://dx.doi.org/10.1037/0021-9010.88.2.207

Kirkman, B. L., Chen, G., Farh, J. L., Chen, Z, X., \& Lowe, K. B. (2009). Individual power distance orientation and follower reactions to transformational leaders: A cross-level, cross-cultural examination. Academy of Management Journal, 52(4), 744-764. http://dx.doi.org/10.5465/AMJ.2009.43669971

Koene, A. S., Vogelaar, L. W., \& Soeters, J. L. (2002). Leadership effects on organizational climate and fieadersh performance: Local leadership effect in chain organizations. Leadership Quarterly, 13, 193-215. http://dx.doi.org/10.1016/S1048-9843(02)00103-0

Langhorn, S. (2004). How emotional intelligence can improve management performance. International Journal of Contemporary Hospitality Management, 16(4), 220-230. http://dx.doi.org/10.1108/09596110410537379

Leban, W., \& Zulauf, C. (2004). Linking emotional intelligence abilities and transformational leadership styles. Leadership and Organization Development Journal, 25(7), 554-564. http://dx.doi.org/10.1108/01437730410561440

Li, L. Q. (2005). Education for 1.3 Billion: Former Chinese vice premier on 10 years of education reform and development. Chin, Foreign Language Teaching and Research Press.

Liao, H., \& Chuang, A. (2007). Transforming service employees and climate: A multilevel, multisource examination of transformational leadership in building long term service relationships. Journal of Applied Psychology, 92, 1006-1019. http://dx.doi.org/10.1037/0021-9010.92.4.1006

Lindebaum D., \& Cartwright S. (2010). A Critical Examination of the Relationship between Emotional Intelligence and Transformational Leadership. Journal of Management Studies, 47(7), 1317-1342.

Martinez, M. N. (1997). The smarts that count. HR Magazine, 42(11), 72-78.

McColl-Kennedy, J. R., \& Anderson, R. D. (2002). Impact of leadership style and emotions on subordinate performance. Leadership Quarterly, 13, 545-559. http://dx.doi.org/10.1016/S1048-9843(02)00143-1

Mind Garden. (2002). MLQ training full range leadership binder. Redwood City, CA: Mind Garden.

National Bureau of Statistics of China. Retrieved from http://www.stats.gov.cn/english/

Nunnally, J. C. (1978). Psychometric theory. McGraw Hill, New York.

Offermann, L. R., Bailey, J. R., Vasilopoulos, N. L., Seal, C., \& Sass, M. (2004). The relative contribution of emotional competence and cognitive ability to individual and team performance. Human Performance, 17(2), 219-243. http://dx.doi.org/10.1207/s15327043hup1702_5

Ozaralli, N. (2003). Effects of transformational leadership on empowerment and team effectiveness. Leadership and Organization Development Journal, 24(6), 335-344. http://dx.doi.org/10.1108/01437730310494301

Palmer, B., Walls, M., Burgess, Z., \& Stough, C. (2001). Emotional intelligence and effective leadership. Leadership 
and Organization Development Journal, 22(1), 5-10. http://dx.doi.org/10.1108/01437730110380174

Parker, G., Gladstone, G., \& Kuan, T. C. (2001). Depression in the planet's largest ethnic group: The Chinese. American Journal of Psychiatry, 158(6), 857-864. ttp://dx.doi.org/10.1176/appi.ajp.158.6.857

Paulhus, D. L., \& Vazire, S. (2007). The self-report method. In R. W. Robins, R. C. Fraley, and R. Krueger (Eds.), Handbook of research methods in personality psychology, 224-239. New York: Guilford Press.

Pawar, B.S., \& Eastman, K.K. (1997). The nature and implications of contextual influences on transformational leadership: A conceptual examination. Academy of Management Review, 22(1), 80-109.

Podsakoff, P. M., Mackenzie, S. B., Moorman, R. H., \& Fetter, R. (1990). Transformational leader behaviors and their effects on follower's trust in leader, satisfaction, organizational citizenship behaviors. Leadership Quarterly, 1(2), 107-142. http://dx.doi.org/10.1016/1048-9843(90)90009-7

Podsakoff, P. M., Mackenzie, S. C., Lee, J., \& Podsakoff, N. P. (2003). Common method biases in behavioral research: A critical review of the literature and recommended remedies. Journal of Applied Psychology, 88, 879-903. http://dx.doi.org/10.1037/0021-9010.88.5.879

Pounder, J. S. (2003). Employing transformational leadership to enhance the quality of management development instruction. Journal of Management Development, 22(1), 6-13. http://dx.doi.org/10.1108/02621710310454824

Prati, L., Douglas, C., Ferris, G. R., Ammeter, A. P., \& Buckley, M, \& R. (2003). Emotional intelligence, leadership effectiveness, and team outcomes. International Journal of Organizational Analysis, 11(1), 21-40. http://dx.doi.org/10.1108/eb028961

Rahim, M. A., \& Minors, P. (2003). Effects of EI on concern for quality and problem solving. Managerial Auditing Journal, 18(2), 150-155. http://dx.doi.org/10.1108/02686900310455146

Rahim, M. A., Zhao, J. H., Yu, C. S., Chan. K. W., Kwok, W. Y., Alves, M. G., Lee. C. W., Rahman, M. S., Ferdausy, S., \& Rene, V. W. (2002). A model of EI and conflict management strategies: A study in seven countries. The International Journal of Organizational Analysis, 10(4), 302-326. http://dx.doi.org/10.1108/eb028955

Robins, R. W., Norem, J. K., \& Cheek, J. M. (1999). Naturalizing the self. In L. A. Pervin and O. P. John (Eds.), Handbook of personality: Theory and research (2nd ed). 443-477. New York: Guilford Press.

Rosete, D., \& Ciarrochi, J. (2005). Emotional intelligence and its relationship to workplace performance outcomes of leadership effectiveness. Leadership and Organization Development Journal, 26(5), 388-399. http://dx.doi.org/10.1108/01437730510607871

Rouche, J, E., Baker, G. A., \& Rose, R. R. (1989). Shared vision: Transformational leadership in American community colleges. Washington, DC: Community College Press,

Rowlinson, S., Ho, K. K., \& Hung, Y. P. (1993). Leadership style of construction managers in Hong Kong. Construction Management and Economics, 1, 55-465.

Rowold, J., \& Heinitz, K. (2007). Transformational and charismatic leadership: Assessing the convergent, divergent and criterion validity of the MLQ and the CKS. Leadership Quarterly, 18, 121-133. http://dx.doi.org/10.1016/j.leaqua.2007.01.003

Salas, E., Dickinson, T. L., Converse, S. A., \& Tannenbaum, S. I. (1992). Toward an understanding of team performance and trainin. In R. W. Swezey, \& E. Salas (Eds.), Teams: Their Training and Performance (pp. 3-29). Westport, CT: Ablex Publishing Corporation.

Salovey, P., \& Mayer, J. D. 1990. Emotional intelligence. Imagination, Cognition and Personality, 9(3), 185-211. http://dx.doi.org/10.2190/DUGG-P24E-52WK-6CDG

Scott, D., Bishop, J. W., \& Chen, X. M. (2003). An examination of the relationship of employee involvement with job satisfaction, employee cooperation, and intention to quit in U.S invested enterprise in China. International Journal of Organizational Analysis, 11(1), 3-17. http://dx.doi.org/10.1108/eb028960

Seltzer, J., \& Bass, B. M. (1990). Transformational leadership: Beyond initiation and consideration. Journal of Management, 16(4), 693-703. http://dx.doi.org/10.1177/014920639001600403

Shamir, B., House R. J., \& Arthur M. B. (1993). The motivational effects of charismatic leadership: A self-concept based theory. Organization Science, 4(4), 577-594. http://dx.doi.org/10.1287/orsc.4.4.577 
Sivanathan, N., \& Fekken, G. C. (2002). Emotional intelligence, moral reasoning and transformational leadership. Leadership and Organization Development Journal, 23(4), 198-204. http://dx.doi.org/10.1108/01437730210429061

Stashevsky, S., \& Koslowsk, M. (2006). Leadership team cohesiveness and team performance. International Journal of Manpower, 27(1), 63-74. http://dx.doi.org/10.1108/01437720610652844

Sternberg, R. J. (1996). Successful Intelligence. NY: Simon and Schuster.

Thorndike, E. L. (1920). Intelligence and its uses. Harper's Magazine, 140, 227-235.

Tischler, L., Biberman, J., \& Mckeage, R. (2002). Linking EI, spirituality and workplace performance. Journal of Managerial Psychology, 17(3), 203-218. http://dx.doi.org/10.1108/02683940210423114

Tsui, A. S., Wang, H, Xin, K. T, Zhang, L. H., \& Fu, P. P. (2004). Let a Thousand Flowers Bloom: Variation of Leadership Styles Among Chinese CEOs. Organizational Dynamics, 33(1), 5-20. http://dx.doi.org/10.1016/j.orgdyn.2003.11.002

Van de vijver, F. J. R., \& Tanzer, N. K. (2004). Bias and equivalence in cross-cultural assessment: An overview. Revue européenne de psychologie appliqué, 54(2), 119-135. http://dx.doi.org/10.1016/j.erap.2003.12.004

Walumbwa, F. O., Lawler, J. J., Avolio, B. J., Wang, P., \& Shi, K. (2005). Transformational leadership and work-related attitudes: The moderating effects of collective and self-efficacy across cultures. Journal of Leadership and Organizational Studies, 11(3), 1-16. http://dx.doi.org/10.1177/107179190501100301

Wang, H., Law, K. S., Hackett, R. D., Wang, D., \& Chen, Z. X. (2005). Leader-Member exchange as a mediator of the relationship between transformational leadership and followers' performance and organizational citizenship behavior. Academy of Management Journal, 48, 420-432. http://dx.doi.org/10.5465/AMJ.2005.17407908

Wang, Yung-Shui., \& Huang, Tung-Chun. (2009). The relationship of transformational leadership with group cohesiveness and emotional intelligence. Social Behavior and Personality: an international Journal, 37(3), 379-392. http://dx.doi.org/10.2224/sbp.2009.37.3.379

Williams, L. J. (1988). Affective and nonaffective components of job satisfaction and organizational commitment as determinants of organizational citizenship and in-role behaviors. Unpublished doctoral dissertation, Indiana University, Bloomington.

Wong, C. S., \& Law, K. S. (2002). The effects of leader and follower emotional intelligence on performance and attitude: An exploratory study. Leadership Quarterly, 13(3), 243-274. http://dx.doi.org/10.1016/S1048-9843(02)00099-1

Wong, C. S., Law, K. S., \& Wong, P. M. (2004). Development and validation of a forced choice emotional intelligence measure for Chinese respondents in Hong Kong. Asia Pacific Journal of Management, 21(4), 535-559. http://dx.doi.org/10.1023/B:APJM.0000048717.31261.d0

Yammarino, F. J., \& Bass, B. M. (1990). Long-term forecasting of transformational leadership and its effects among naval officers: Some preliminary findings. In K. E. Clark, \& M. B. Clark (Eds.), Measures of Leadership (pp. 151-169). West Orange, NJ: Leadership Library of America. 